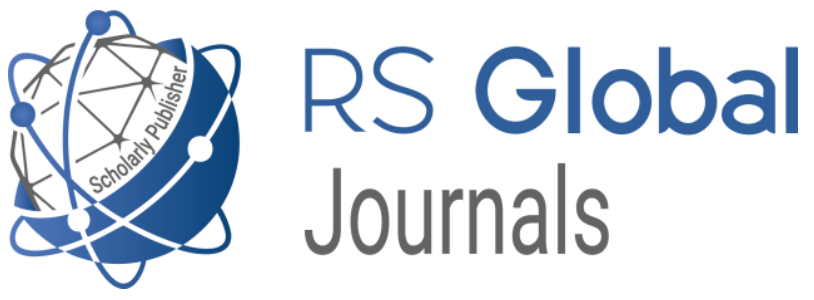

Scholarly Publisher

RS Global Sp. z O.O.

ISNI: 0000000484952390

Dolna 17, Warsaw, Poland 00-773

Tel: +48226022703

Email: editorial_office@rsglobal.pl

JOURNAL International Journal of Innovative Technologies in Social Science

p-ISSN

$2544-9338$

e-ISSN

2544-9435

PUBLISHER

RS Global Sp. z O.O., Poland

ARTICLE TITLE

SENSATIONAL UNKNOWN FACTS FROM GEORGIAN DIPLOMACY OF 90-IES OF XVIII CENTURY

AUTHOR(S)

Mamuka Natsvaladze

Mamuka Natsvaladze. (2020) Sensational Unknown Facts from

ARTICLE INFO

Georgian Diplomacy of 90-ies of XVIII Century. International Journal of Innovative Technologies in Social Science. 7(28). doi: 10.31435/rsglobal_ijitss/30122020/7291

DOI https://doi.org/10.31435/rsglobal_ijitss/30122020/7291

RECEIVED

29 October 2020

ACCEPTED

10 December 2020

PUBLISHED

15 December 2020

(c) (7)

LICENSE

This work is licensed under a Creative Commons Attribution 4.0 International License.

(C) The author(s) 2020. This publication is an open access article. 


\title{
SENSATIONAL UNKNOWN FACTS FROM GEORGIAN DIPLOMACY OF 9O-IES OF XVIII CENTURY
}

\author{
Mamuka Natsvaladze, \\ Sokhumi State University, Tbilisi, Georgia
}

DOI: https://doi.org/10.31435/rsglobal_ijitss/30122020/7291

\section{ARTICLE INFO}

Received 29 October 2020

Accepted 10 December 2020

Published 15 December 2020

\section{KEYWORDS}

Erekle the Second,

Agha Mohammad Khan,

the Empire of Austria,

the Russian Empire,

the Kingdom of Kartli and

Kakheti,

Vienna.

\begin{abstract}
The Italian translation of Erekle the Second's letter maintained in the archive of Vienna which was published in 1979 by Professor Ilia Tabaghua, reveals a sensational secret. In this letter we found a unique delf unveiling the fact that after the Krtsanisi tragedy suffered in 1795 Erekle the Second addressed Europe. In the course of studies and analyses we came across several delfs in one document that had been considered to be one letter, namely, in the Italian translation of a letter by Erekle the Second; chronologically these delfs turned out to be significantly distant from one other. Further studies conducted on these delfs brought us to the conclusion that in 1795, after the Krtsanisi tragedy, Erekle the Second's ambassadors arrived to Vienna and handed the letter to the Emperor of Austria.

In the Italian translation of a document by Erekle the Second that had been considered by scientists to be one single letter and which is dated with 1782 , the fragment saying that "in these days the king's residence in the East was totally destroyed" caused the first suspicion.
\end{abstract}

We want to especially underline the circumstance that there is no evidence of destruction of any city or a town what could be considered to be the eastern residence of the king, found in the 80-s of the XVIII century. Therefore, there is only one way left - we should accept it that Erekle the Second is speaking about the fact of Agha Mohammad Khan destroying Tbilisi in 1795 - the tragedy that took place 13 years later. It is another fact that in 1782 Erekle the Second had no means to write about the events that would have taken place in 1795.

And thus, we have come to the conclusion that the Italian translation of the letter by Erekle the Second prepared by the chancellery of the Emperor of Austria based upon the letter sent by Erekle, is not a single letter but a compilation of at least two letters written by him. We should give due significance to the fact that the mentioned Italian translation does not contain any specific personalized addressee but is addressed to the Emperor of Austria, not revealing to which of the Emperors it addresses namely. The translation does not contain any concrete date either.

The article provides review of the purposes and goals that the ambassadorial mission of late fall of 1795 sent by the king Erekle to the Emperor of Austria as well as other delfs of the above mentioned letter that cause suspicion and that unambiguously confirm it that certain fragments of the letter are written in 1795 which on its part implies confirmation of the fact that in the late fall of the year 1795 there had place a diplomatic communication between the Austrian Empire and the Kingdom of Kartli and Kakheti.

This latter fact abolishes the view that had been established in historiography up today that Erekle the Second unconventionally turned to Russia after Agha Mohammad Khan brought Tbilisi to earth in 1795 .

Citation: Mamuka Natsvaladze. (2020) Sensational Unknown Facts from Georgian Diplomacy of 90-ies of XVIII Century. International Journal of Innovative Technologies in Social Science. 7(28). doi: 10.31435/rsglobal_ijitss/30122020/7291

Copyright: (C) 2020 Mamuka Natsvaladze. This is an open-access article distributed under the terms of the Creative Commons Attribution License (CC BY). The use, distribution or reproduction in other forums is permitted, provided the original author(s) or licensor are credited and that the original publication in this journal is cited, in accordance with accepted academic practice. No use, distribution or reproduction is permitted which does not comply with these terms.

Introduction. Italian translation of the letter of Erekle II preserved in the State Archive of Austria (Österreichisches Staatsarchiv, Haus-Hof-und Staatsarchiv, 1010 Wien, I, Minoritenplatz I) keeps a sensational secret [Tabaghua 1979:105-107]. We have deciphered and studied the letter sent to the Emperor of Austria by the King of Kartli-Kakheti, proving the issue that the King of KartliKakheti contacted Europe after Krtsanisi Tragedy of 1795. 
A scientific novelty. This is an unknown fact in historiography, that needs a fundamental review of the history of Georgia of the referred period.

A scientific novelty with a view of source study can be different themes and issues revealed based on the thorough research and analysis of a document, formerly considered to be one letter, in particular, Italian translation of a letter of Erekle II sent to the Emperor of Austria. The themes are significantly different with a chronological point of view. Study of the referred issues made us conclude that after the Krtsanisi Tragedy, Ambassade of Erekle arrived in Vienna and transferred a letter to the Emperor [Natsvaladze 2020a:79; Natsvaladze 2020b:7-8].

Before it, there were two Ambassades - in 1781 Pater Domenico took the messages of Erekle to Vienna, but they could not reach the place of destination, since he passed away in unknown circumstances in Constantinople. Due to the urgency of the case Erekle sends the second Ambassade a year later, in 1782 Patri Mauro Veronelli was commissioned to transfer the message of Erekle to the Emperor of Austria orally [Tamarashvili 1902:402]. This Ambassade also failed - Patri Mauro died in suspicious circumstances in Berdychiv, Poland, but, unlike the first Ambassade, Erekle's correspondence reached its destination [Shvelidze 2014:33-38]

Sources. The referred correspondence of the King of Kartli-Kakheti and related records of Vienna Imperial Court Chancellery are preserved in the materials of Austrian State Archives in different volumes, sorted by country (Russia, Sardinia, Venice, France, Persia), as well as in the archives of Vatican and Venice. Approximately forty letters on the topic of Georgia have been traced, but most of them are available in the form of Italian translation. The referred documents have been found and published by Ilia Tabaghua. The correspondence sent by Erekle was published by the scientist in Georgian and Italian languages [Tanaghua1979:77-185]

Research methods. We rely on the methodological principles of objectivity, historicism, determinism, alternativeness, reconstruction, developed in the theoretical studies by the following scientists: Charles-Victor Langlois, Charles Seignobos; Robin George Collingwood [Collingwood 1993]; Marc Léopold Benjamin Bloch [Bloch 1952]; Peter Lambert and Phillipp Schofield [Lambert, Schofield 2004]; Abrams Lynn [Abrams Lynn 2010]; Brundage Anthony [Brundage 2017]; Gregory Ian, Ell Paul [Gregory Ian, Ell Paul 2008]; Hughes-Warrington [Hughes-Warrington 2007]; Iggers George, Wang Qiang Edward [Iggers, Wang 2013]; Akira Iriye [Iriye 2012]; Kaldellis Anthony [Kaldellis Anthony 2014]; Koselleck Reinhart [Koselleck 2004; Koselleck 2002]; Lukacs John [Lukacs John 2000]; Munro Doug, Reid John [Munro Doug, Reid John 2017]; Quigley Carroll [Quigley Carroll 1979]; Raaflaub Kurt [Raaflaub Kurt 2010].

Research results. The study and analysis of Erekle's letters preserved in the European archives allows us to confirm sending the Ambassade to the Emperor of Austria after the devastation of Tbilisi in 1795 [Natsvaladze 2020a:79; Natsvaladze 2020b:7-8]. Based on the available documentary material, only fragmentary, though conceptual features of the unknown Ambassade can be outlined at this stage. However, finding and obtaining complete information is a matter of future.

The issue of Erekle's relations to Austria was considered by Mikheil Tamarashvili [Tamarashvili 1902], Ilia Tabaghua [Tabaghua 1979], Sargis Kakabadze [Kakabadze 1997], Iase Tsintsadze [Tsintsadze 1960:111-120]. The referred topic was also reviewed by Dimitri Shvelidze [Shvelidze 2014:33-38], Giorgi Kalandia [Kalandia 2017], Mikheil Samsonadze [Samsonadze 1988:230], Vakhtang Peradze [Peradze 2006:89-90]. Nino Doborjginidze [Doborjginidze 2013; Doborjginidze 2019] and Maia Damenia [Damenia 2017] worked in different archives of Rome.

It is noteworthy that until the present moment none of the researchers has referred to the problem raised by us. Accordingly, the Ambassade sent to Austria by Erekle in 1795 is an unknown fact in historiography and the most important novelty.

Correspondence sent by Erekle have different addressees - Emperor of Austria, Kings of Prussia, France and Venice. The letters were brought to Vienna after the death of Patri Mauro Veronelli (sent to Austria) in the city of Berdychiv, Poland.

The Austrian Imperial Court pays special attention to the translation of these letters. It is obvious that Vienna has a thorough understanding of the role of Georgia as a strategic partner in the fight against the Ottoman Empire established as a system model in a form of "Greek Project" by the joint agreement of the Austrian and Russian Emperors in the 80-ies [Ragsdale 1988:95-105]. Furthermore, it is also evident that the Imperial Court of Vienna seeks relations with Georgia for the full implementation of the Greek Project. Therefore, it considers the process of translating the letters sent by Erekle with great diligence and seriousness lasting more than a year. 
It is quite an important detail that Wencel Kaunitz, a world-class diplomat whose name is associated with the diplomatic revolution of the Seven-Year-War, took care of translating the letters and presenting them to the Emperor. The rapprochement of Austria and France, being enemies for centuries, is a result of the diplomatic work of Kaunitz [Ivonin 2007:32-44; Monastyreva 2009:157-161].

It is noteworthy, that correspondence (approximately 40 letters) referring to Georgia and preserved in the archives of Vienna, Vatican and Venice [Tabaghua 1979:105-107], actually contain the same topics. In particular:

1. Beyond the problems posed in Erekle's letters there is a mysterious and urgent message of Erekle that Mauro Veronelli must report to Joseph II, the Emperor of Austria during his audience. No information is contained in the letters about the details that should be personally notified to the Emperor of Austria by Mauro Veronelli.

2. Friendly relations with Austria is a traditional desire of the Kings of Georgia, ancestors of Erekle;

3. Erekle requests financial support from Austria for hiring and training 2 regiments in the European manner;

4. Kings of Georgia traditionally have favorable relations with Russia which always helps them. Consequently, Austrian-Georgian relations at the request of Erekle cannot bring dissonance in Russian-Georgian and Russian-Austrian relations.

It is important, that the letter of our interest published by Ilia Tabaghua with a number 22 (hereinafter referred as the Letter No.22), repeats only the first two paragraphs of topics of correspondence sent to Europe by Erekle II. It contains no information regarding the relationship with Russia or funding two regiments.

Furthermore, it contains certain facts and motives not mentioned in other letters. That is why the Letter No.22 rises many questions.

This letter actually differs from other correspondence of Erekle to the extent of its multifaceted content and emotional mood, composed in academic style and in full compliance with diplomatic etiquette, however prevailing of emotions is observed in the Letter No.22.

The most important detail is that unlike previous letters, this letter does not have a personified addressee, it has only a general reference - the Emperor of Austria. It is not specified which Emperor of Austria this message belongs to. It is also noteworthy that the letter of our interest has no date either. The Italian translation of Erekle's letter is preserved in the Archive of Vienna. However, Georgian original has not been found yet.

A variety of content layers is observed in this letter actually failing to coincide the date of writing the latter. The referred circumstance indicates that this Letter No.22 is not a single letter but a compilation of letters sent by Erekle in different times, prepared by the imperial chancellery specifically for the Emperor of Austria to thoroughly understand the problems related to Georgia.

At first glance, defining the date of writing the letter seems simple taking into consideration the well-known fact stated in the letter itself.

Erekle writes: „I sent Patri Domenico, living in Tbilisi, to Your Imperial Royal Majesty last year. He was accompanied by many servants and translators" [Tabaghua 1979:106-107].

It is a confirmed fact that Erekle sent Patri Domenico to the Imperial Court of Vienna in 1781. Consequently, this letter should have been written in 1782 and taken to Vienna by Patri Mauro Veronelli. However, a number of content layers suggest that this is not a single letter, but a compilation of several letters composed at different times, since the facts indicated in it reflect the events happening after 1782 .

The letter gives expression that its creation was preconditioned by an important event and the referred event took place after Erekle's first letter had already been written.

Here, the first doubt arises - Why Erekle II needed to send two letters to the same addressee at the same time and within one Ambassade that would notify the Emperor of Austria the same event in different ways. If there was a need of any clarification, why it was not done within the mode of a single correspondence. Moreover, it could be easily done as in 1782 publications were sent from Tbilisi to Europe in Georgian and not their Italian translations.

Following issues rise the doubts in particular:

a) It is quite simple to date the correspondence sent to the Emperor of Austria; However, it is unclear how the letter contains a fact relating to an event taking place 13 years after it was written.

The following fragment (quotation) of the existing text - "These days East Royal Residence was completely destroyed" - clearly indicates that it refers to the tragedy of 1795 . It is obvious that Erekle could not have written anything about it when composing this letter in 1782. 
b) The fact that the letter starts with reprimand and reproach towards the Emperor of Austria also raises a question. It is undisputed that no relationship, neither human nor diplomatic, starts with a reprimand or reproach.

c) Erekle referring the Emperor of Austria as "Sultan". We can firmly state that Erekle would not have called the Emperor of Austria a "Sultan".

Besides these peculiar points, the letter contains two extremely important fragments not mentioned in the rest of the letters sent to Europe by Erekle.

1. Preparation of alliance agreement "reinforced by oath" with the Austrian Empire. This is a totally new segment in the Georgian History of 80-90-ies of XVIII century. It should be clarified when Erekle might have offered the Emperor of Austria a relationship "reinforced by oath" - in 1782 or in 1795.

2. The letter contains extremely important information about the first Ambassade sent by Erekle in 1781. It should be specifically noted that only this letter of Erekle contains information that Domenico, who was sent to Europe in 1781 did not go there alone and he was accompanied by a numerous retinue (quotation): "I sent Patri Domenico, living in Tbilisi, to Your Imperial Royal Majesty last year. He was accompanied by many servants and translators ... " [Tabaghua 1979:106-107].

Hereinafter, we will review each inappropriate issues separately.

The following fragment (quotation) - "These days East Royal Residence was completely devastated and all great and powerful wild enemies came against us. We lack necessary military weapon. Hand-to-hand fighting will be less helpful for us" - clearly indicates that the correspondence of Erekle II sent to the Emperor of Austria and published by Ilia Tabaghua as the Letter No.22 is not a single letter [Tabaghua 1979:107].

We would like to underline and explain that "complete destruction of East Royal Residence" is the event of a great significance and it would have been reflected in all letters of King Erekle due to its multifaceted importance. This kind of repetition is characteristic of the correspondence of Erekle the same problem of similar content is repeated in different letters in various modes.

Otherwise, it is surprising that among Erekle's letters, the referred fact is mentioned only in the Letter No.22. It is of paramount importance to find out the exact city mentioned by Erekle as completely devastated.

The question is whether Erekle meant the fall of Constantinople on May 29, 1453. The massive devastation of the East Royal Residence is contextually much closer to that event. However, taking into consideration that Erekle points to the referred event as "taking place these days" the version related to Constantinople shall be completely ruled out.

For Georgians, the tragedy similar to the scales of Constantinople and mentioned in this letter, shall be dated by the 80 -ies of XVIII century.

The fact of ruining the city that can be considered as East Royal Residence is not confirmed in the 80-ies of XVIII century. For this period, only the fact of large-scale devastation of Yerevan is mentioned in the sources initiated by Erekle himself.

Omar Kherkheulidze, chronicler of Erekle II gives following description of the event (quotation): "And in the year 1780 chronology 467 (Byzantine 532-year cycle), Khan of Yerevan Aslan Ali-Khan refused to give tribute... and King Erekle immediately ordered to gather KartliKakheti army as well as the army of several thousands of Lezgians and went in August of the same year and stopped in the village of Shirabat, that is far from Yerevan about two house shell and the army started ruining Yerevan and no building was left apart from Yerevan and Etchmiadzin“ [Kherkheulidze1989:69-70].

Naturally a question arises - to what extent a completely devastated Yerevan can be considered as "East Royal Residence". This version shall be completely ruled out. On the one hand, Yerevan was not considered as "East Royal Residence" and on the other hand such large-scale punishment of this city was initiated by Erekle himself. Therefore the King of Kartli-Kakheti would neither have reproached anyone for ruining that city and nor have mentioned the referred fact in the letter sent to the Emperor of Austria. Moreover, Erekle would not have paid special attention to it.

We might also assume the version that Erekle is striving to draw a sharp tragic picture for Europe in order to give more argumentation and motivation for the realization of the idea of alliance. It should be noted that the tactics of this kind was sometimes used by the Kings of Georgia, especially Teimuraz I. However, this version and the manipulation of this type shall be also ruled out from Erekle's side, since his thinking style and attitudes towards a foreign country were based on highly deliberate relationships and real arguments. 
Besides, geostrategic importance of Georgia and interest towards the latter is so great that not understating it by the European states and not using the benevolence of Erekle and Georgian Royal Kingdoms clearly means refusing a really successful project.

There is one more factor - during Erekle's time there was a large flow of Catholic missionaries in Georgia, that was an information agency transmitting real information to Europe. With such a properly maintained information infrastructure, it is obvious that Erekle would not have ventured on such an adventure, for the simple reason that he did not need it at all.

In this respect, we think to completely rule out the possibility that Erekle might mean the events of Yerevan while referring to the complete devastation of the "East Royal Residence" or that he might dramatize non-existent event.

This conclusion turns everything upside down. It is obvious that in the letter of 1782 Erekle could not have written anything about the events taking place 13 years later. Therefore, we should come to a conclusion that the referred fragment existing in the Italian text could not be Erekle's letter written in 1782 . That is a fragment of a later letter and should possibly mean the devastation of Tbilisi by Agha Mahmad-Khan in 1795.

It is also clear that "Devastation of the East Royal Residence" and the events of 1795, were quite painful for Erekle. Therefore, we must look for the origins of this letter, characterized with exaggerated emotional context, in Erekle's mood depressed psychologically.

In order to find the explanation of this letter the only solution is to admit that this fragment was not written in 1782. It was written 13 years later when the East Royal Residence, Tbilisi, was devastated really and completely. On the whole this different layer proves that we refer not to a single letter, but to a compilation of at least three several letters written at different times, created by the Chancellery of the Austrian Imperial Court for the Emperor.

The existence of this compilation letter containing a fragment of 1795 , is unequivocal proof that Erekle should have sent the third Ambassade to the Austrian Imperial Court.

Naturally, the question arises - what was the aim of a compilation document? We should explain that Austria was ruled in 1795 by a completely different emperor - Franz II, nephew of Joseph II, who was less familiar with the previous history of the issue. In order to make the new emperor of Austria understand the events well, according to the existing bureaucratic practice, the imperial chancellery prepared a kind of compilation material, containing information on previous AustrianGeorgian relationships and description of the events of 1795 as well.

Accordingly, Letter No.22 obtained and published by Ilia Tabaghua is in fact a compilation of different letters. Our opinion is supported by the fact that the letter bears neither specific identity of the Austrian Emperor nor the date.

The existence of the letter as a compilation document composed of various correspondences is confirmed by another interesting point - Erekle calls the Emperor of Austria a "Sultan" in one section of a letter. This inaccuracy obviously comes from copying and we rule out the possibility of making such inaccuracy due to the importance of Ambassade and Erekle's special attitude towards the event.

Erekle addresses the Emperor of Austria: „My Merciful and Perspicacious Sultan“. Similar text is contained in the Italian original - „Mio Clementissimo, osservandissimo Soldano“ [Tabaghua 1979:139]. We categorically rule out that one Christian ruler can call another Christian ruler a Sultan. This error might have been made by the compiler, though it cannot reduce the purpose of the compilation of letter. However, it also preserved the issues of the unknown letter addressed to an alien Muslim Ruler currently unfamiliar to us.

One more trace is also observed in the beginning of the letter, that contains a rather strange contextual and emotional layer (quotation): «In our agreement it is important for your servant to show sincerity, for no service from the side of your servant to the Imperial Service of Your Majesty will achieve its result, nor will it show distant defensive loyalty under the pretext of opposite arguments... May it never happen that our friendly mood and aspiration turn into a serious misunderstanding upon passing the time that will hamper our missioner performing the duties of a 'Messenger'» [Tabaghua 1979:105-106].

The obvious tone of reprimand towards the Emperor in the beginning of Erekle's letter is rather strange. Erekle clearly underlines the factor of loyalty. Obviously, something is happening from the part of the Austrian Royal Court, or the missionaries, or any other fact stipulating to raise this issue.

The psychological sub-text of this point can be used as confirmation that the referred letter could not have been the first one sent by Erekle to the Emperor of Austria. The reason is quite simple, it is impossible to initiate relationship between to countries or rulers with reprimand and reproach. 
Such situations are ruled out even in simple human relationships. Moreover, no one starts relations with reprimands and reproaches on a diplomatic fields.

Erekle II is an exceptionally reserved politician. Therefore, within the frameworks of his deliberate and highly unemotional diplomatic relations, coming out from the interests of his nation, the clear reprimand not even an emotional tone observed in the letter sent to the Emperor of Austria is rather noticeable and quite strange.

This strange sub-text should obviously have some preconditions. It is interesting, what happened or became known to Erekle that caused the indignation of the latter and could not hide his emotions in the letter?

If we accept the fact that the letter was written in 1782, and it is a single, whole letter and not compilation, the question will remain unanswered, since Mauro Veronelli had not started travelling towards Vienna and there would have been no news moreover regarding the relationship of Austria and King of Kartli-Kakheti referring to the loyalty to certain principles. This relationship is not an established fact and naturally, it is impossible to measure it with any component at that stage.

Actually, it is incredible for every person to start relations in terms of such a reprimanding tone. This fact confirms once again that the referred fragment is not from the letter of 1782 and it is a part of the one reflecting the events of 1795 that should have been inserted by the compiler into the document prepared for the Emperor from the letter of the third Ambassade.

Complex study of Erekle's letters, international political situation and relationship with Russia made us conclude that during the period 1782-1795 Erekle sent one more Ambassade to the Imperial Court of Austria, where a "Persian Project" of Erekle should have been reviewed together with the "Greek Project". Herein, we cannot rule out that this emotional letter results from Erekle's negative mood towards Russia due to multiple Anti-Georgian performances. We mean certain facts: Attempt to liquidate Erekle II through Totleben and then oust of Erekle from the throne of Kartli-Kakheti by Captain Lvov [De Gray de Foie 1985:35-59] the insulting attitude of the Russian Imperial Court towards the ostensible ally, the official ambassador of Kartli-Kakheti [Buleishvili 1987:60-63], followed by the cascade of similar political adventures - assassinations of Prince Levan [Tukhashvili 1983; JambakutOrbeliani 1914:14-18; Berdzenishvili 1973:255-262] and then of the Ambassadors sent to the Emperor of Austria [Tabaghua 1979:79-126; Kalandia 2017:11-14; Peradze 2006:84-89] rise of various adventurers at the Royal Court of Kartli-Kakheti, [Shvelidze 2012:108-112; Gelashvili 2002:130-138; Guruli 2015:33-35] poisoning of the future king-Giorgi, [Natsvaladze 01.05.2017:15] concluding the Treaty of Georgievsk [Guruli 2013a:23-33; Paitchadze 1983:62-65; Macharadze 2013:109-120; Papashvili 2003:307-310] than violation of the referred treaty [Guruli 2013 b:18-20; Lobzhanidze 1989:235-237]... The crown of this cascade of intrigues is the devastation of Tbilisi in 1795 by Agha Mahmad-Khan [Metreveli 2018:90-92; Potto 1891:1-2; Muskhelishvili 2012:379-382; Tsintsadze 1969:170-175], accordingly, Erekle has no desire to develop relations with Austria in a similar manner.

These are the sentiments of a heartbroken person who has been disappointed and actually faced the shortage of loyalty. This letter is a good example of the moral and psychological tensions that Erekle has to endure the traditional Russian anti-Georgian policy, the one he analyzes and knows in details.

It is not surprising, those psychological pessimistic sentiments were intensified after Russia failed to meet its obligations undertaken by the Treaty of Georgievsk. However, another question arises here - what does the Austrian emperor have to do if Russia does not fulfill its obligations? To what extent does this give grounds for Erekle to reprimand the Imperial Court of Vienna instead of Russia?

We think, there might have been some relations between Vienna and Tbilisi on the background of systematic ignorance of Georgian interests from the side of Russia. It is also obvious that within the common interests of the three states, Vienna could make some influence on St. Petersburg in favor of Georgia. With this reprimand, Erekle calls for Austrian Royal Court to take more active action, especially since it is obvious that the three states have concurrent goals and aspirations towards the Ottoman Empire, at least based on the official version [Arneth 1869:211-220; Griffiths 2013:357-365].

Conducted review of the fragment of the document we are interested in and presented arguments are further proof that the letter sent to the Emperor of Austria is a compilation, it reflects the psychological moods and sentiments of the events taking place in 1795 and could not have been written 1782 accordingly.

Letter No.22 contains one more issue proving its compilatory format. Erekle clearly understands that relations with the Austrian Empire should not be one-time, but "reinforced by oath." 
It is obvious that Erekle prefers an alliance agreement "reinforced by oath" that can be the basis for further relations and therefore certain proposals of the alliance agreement shall be notified orally to the Emperor of Austria by Mauro Veronelli, ambassador of Erekle. The King of Kartli-Kakheti writes: "We have two motives in this section: the first is the request of Christianity; the second, if you deem it appropriate, it is necessary to make an oath to encourage our polite appearance in your highest residence for ever" [Tabaghua 1979:105-106].

However, there is another detail - as the Letter No.22 is a compilation of letters written by Erekle in different times, the possibility that Erekle might have offered Austria to establish relations "reinforced by an oath" cannot be ruled out. The real grounds for such decision existed in 1781-82 and later in 1795 as well. We think, the third Ambassade of Erekle to Vienna Imperial Court was prepared for that purpose.

It is a fact that issue of allied relations with Georgia remains actual for Austria trying to activate the available trump card of the "Holy Roman Empire". This bilateral interest is still obvious in spite of the Treaty of Georgievsk concluded between Erekle and Russia. This can be the explanation of the fact that Imperial Cour of Vienna holds a German translation of the Treaty of Georgievsk [Tabaghua 1979:158-171]. Accordingly, during the subsequent period, the vector of political interests of Austria and Georgia should have been crossed clearly due to their identical directions, especially after the tragedy of 1795 .

Herein, not a minor detail at all - in the letter Erekle underlines that his ancestors, Georgian kings, also aspired to relations with Austria, therefore his desire to have relations with the Imperial Court of Vienna is the fulfillment of their desires.

"In the past, our forefathers were eager and desirous to reach the glorious court of my enlightened and merciful Patron with a cherished request and make their wish come true, but they could find neither time nor occasion to do it because of a powerful Muslim Sect. And now, with help and support, we have found our own strength and will to express the desire and request of our forefathers..." [Tabaghua 1979:106].

Conclusions. Thus, based on the documentary primary sources and above mentioned analysis, the Italian translation of the letter sent to the Emperor of Austria by Erekle unambiguously proves following statements:

1. Erekle II sends Ambassade to the Emperor of Austria after the invasion of Agha MahmadKhan in 1795.

2. Unlike secret goals of the previous Ambassade, goals of this Ambassade is absolutely open and unambiguous - to take an oath and long-term, business relationships with Austrian and Holy Roman Empire.

3. The opinion that Erekle II was obsessed with the idea that the only way to save Georgia was through Russia is absolutely ruled out by the fact of Ambassade 1795.

4. Erekle strives to make his kingdom part of European politics independently, after Russia violates the terms of the treaty and fails to fulfill the undertaken obligations.

5. In 70-80-ies of the XVIII century Erekle tries to strengthen relations with Austria within the framework of the current "Greek Project", since its political interests are rather closer with the Georgian ones.

6. The actuality of Christian globalization model as a prevention of security from the Muslim environment is highlighted in the letter. According to Erekle's version it could be fulfilled through joint implementation of Greek and Persian projects. Concluding the sworn agreement with the Emperor of Austria might have served that purpose.

7. The Imperial Court of Austria is especially interested in this relationship. Accordingly, Erekle's proposals are reviewed trhough the compilation material prepared by the Chancellery of the Imperial Court.

8. Emperor of Austria, being the Holy Roman Emperor as well, strives to utilize the reserves of actually unfunctional political segment "The Holy Roman Empire", therefore Erekle's proposal is important for him as well.

9. Another novelty in historiography is also observed - Besides the unknown Ambassade of 1795, after 1782 Erekle should have sent one more Ambassade to Austria before the invasion of Agha Mahmad-Khan. 


\section{REFERENCES}

1. Arneth 1869 - Joseph II und Katharina von Russland. Ihr Briefwechsel, hrsg. von Alfred, Ritter von Arneth, Wien, 1869 s 446

2. Abrams Lynn 2010 - Abrams Lynn. Oral History Theory, London: Routledge, 2010. 224 p.

3. Berdzenishvili 1973 - Berdzenishvili, N. Death of Levan Batonishvili. Issues of Georgian history 6. Nikoloz Berdzenishvili. Tbilisi 1973. pp 452-474

4. Buleishvili 1987 - Buleishvili, M. Kartli-Kakheti Embassy to Russia in 1772-1774 headed by Catholicos Anton and Leon Batonishvili (Royal Prince). Issues of the History of Religion and Atheism in Georgia. USSR Science Academy of Georgia; Simon Janashia Museum of Georgia Tbilisi, 1987. p. 50-74

5. Brundage 2017 - Brundage Anthony. Going to the Sources: A Guide to Historical Research and Writing, $6^{\text {th }}$ Edition. Wiley-Blackwell, 2017. 168 p.

6. Bloch 1952 - Bloch M., Apologie pour l'histoire ou métier d'historien. Librairie Armand Colin, Paris, 2 édition,1952, 112 pages.

7. Collingwood 1993 - Collingwood R. G., The Idea of History. Rev. ed., edited and with a new introduction by J. van der Dussen, Clarendon Press, Oxford, 1993. 510 p.

8. Damenia 2017 - Damenia m. Description of the first volume Archives of Propaganda Fide. Cadmus 9, 2017 195-211

9. De Grailly De Fois 1985 - De Grailly De Fois - About Georgia, translated from French, foreword, notes and tables and bibliography by JumberOdisheli, "Metsniereba" ("Science"), Tbilisi, 1985, p. 109

10. Doborjginidze 2013 - N. Doborjginidze, For Reconstruction of the Historical Memory, compilation of works: "Zurab Kiknadze-80“, Tbilisi, 2013 pp 234-257

11. Doborjginidze 2019 - Doborjginidze N. European Projection of Erekle II and His Kingdom. Cultural traces of Georgians in Germany, Tbilisi, Ilia State University, 2019. p. 166-218

12. Gelashvili 2002 - Traveling Through Georgia. Jacob Reineggs; Translation from German, introduction and bibliography by Gia Gelashvili. „Artanuji” publishing, Tbilisi, 2002; p. 333

13. Gregory Ian, Ell Paul 2008 - Gregory Ian N., Ell Paul S. Historical GIS: Technologies, Methodologies, and Scholarship, Cambridge University Press, 2008. 240 p.

14. Guruli 2015 - Guruli V. Shady Enterprise of General Gottlob Tottleben in Georgia, My World, Foundation of Study of Strategies and International Relations of Georgia. Tbilisi, 2015, October. pp. 32-39.

15. Guruli 2013 A - Guruli V. Treaty of Georgievsk (1783) Tbilisi: "Universal", 2013. p. 56 Guruli 2013 B Guruli, V. Treaty of Georgievsk: Under the "Protection" by the Empire: from the Very Beginning the Russian Empire Was Determined Not to Fulfill the Terms of the Agreement, „Istoriani”: a historicaleducational journal. Tbilisi, 2013. July, N7(31), pp. 17-22

16. Griffiths 2013 - Griffiths David M. Did Ekaterina the Great Have the «Greek Project" Ekaterina the Great and Her World: articles of various years. David Griffiths; M.: "Novoe Literaturnoe Obozrenie" 2013. pp 349-368

17. Hughes-Warrington 2007 - Hughes-Warrington M. Fifty Key Thinkers on History, London: Routledge, $2007,480 \mathrm{p}$.

18. Ivonin 2007 - Ivonin Y. Wenzel Anton Kaunitz. History questions. 2007. No. 4. S. 27-50.

19. Iggers, Wang 2013 - Iggers George G., Wang Q. Edward (authors), Mukherjee Supriya (contributor). A Global History of Modern Historiography, Routledge, 2013. 448 p.

20. Iriye 2012 - Iriye A. Global and Transnational History: The Past, Present, and Future, New York: Palgrave Pivot. 2012. 96 p.

21. Jambakur-Orbeliani 2014 - Jambakur-Orbeliani, A. Lezgins Coming out of Dagestan and Other Stories, Al. Jambakur-Orbeliani, patronymic Vakhtang, published by Sargis Kakabadze according to the autograph protected in the Society Spreading Literacy. Tfilisi, 1914, p. 23

22. Kakabadze 1997 - Kakabadze S. History of Georgian People, 1783-1921. Tbilisi, Nekeri 1997. p. 276

23. Kalandia 2017 - King Erekle in the English and Irish Press, the information was collected, introduction and comments were provided by Giorgi Kalandia 2017332 p

24. Kherkheulidze O. Reign of Erekle II. The text was prepared for publication with the research, dictionary and bibliography by Lela Mikiashvili. Tbilisi, Metsniereba, 1989. p.128

25. Kaldellis Anthony 2014 - Kaldellis Anthony. A New Herodotos. Laonikos Chalkokondyles on the Ottoman Empire, the Fall of Byzantium, and the Emergence of the West, Dumbarton Oaks, 2014. 324 p.

26. Koselleck 2004 - Koselleck Reinhart. Futures Past: On the Semantics of Historical Time, Columbia University Press, 2004. 336 p.

27. Koselleck 2002 - Koselleck R. The Practice of Conceptual History: Timing History, Spacing Concepts, Palo Alto: Stanford University Press, 2002, 384 p.

28. Lukacs John 2000 - Lukacs John. Student's Guide to the Study of History, ISI Books, 2000. 53 p.

29. Lobzhanidze 1989 - Lobzhanidze, G. A Study from the History of Legal Relations between Russia and Georgia: [The Legal Status of the Treaty of Georgievsk and Making Georgia a Non-sovereign State, Unilateral Violation of the Agreement by Russia] "Gantiadi”. Kutaisi, 1989. N6, pp.232-237

30. Langlois, Seignobos 1992 - Charles-Victor Langlois, Charles Seignobos, Introduction aux études historiques. Editions Kimé, Paris, 1992, 284 p 
31. Lambert, Schofield 2004 - Lambert P. and Schofield P. Making History: An introduction to the history and practices of a discipline. Routledge, 2004 - 310 pages

32. Macharadze 2013 - Macharadze, V. Three Treasures of the Treaty of Georgievsk: Scientific-Public Journal. Tbilisi, 2013. March, N1(7), pp. 100-137

33. Munro Doug, Reid John 2017 - Munro Doug, Reid John G. (eds.). Clio's Lives: Biographies and Autobiographies of Historians, Acton: ANU Press, 2017. 330 p.

34. Metreveli 2018 - Metreveli, R. Agha Mohammad Khan's Ultimatum to King Erekle the II, Matsne = "Izvestia" = Proceedings / Georgian National Academy of Science. Tbilisi, 2018. N 2. The series of history, archeology, ethnology and the history of arts, pp. 88-97

35. Muskhelishvili 2012 - Muskhelishvili, D. Agha Mohammad Khan Attacking Georgia: The History of Georgia: From the Ancient Times to 2009 / D. Muskhelishvili, M. Samsonadze, A. Daushvili; editor: D. Muskhelishvili. Tbilisi, 2012. pp. 375-385

36. Monastyreva 2009 - Monastyreva L.Y. Kaunitz's reforms in the diplomatic service in Austria in the second half of the 18th century. Bulletin of the Smolensk State University. 2009. No. 4 (8). p 153-162.

37. Natsvaladze 2020a - Natsvaladze M. Unknown Details of the 1795 Ambassadorial Mission of Georgia to Europe $15^{\text {th }}$ International Silk Road Virtual Conference. Book of Abstracts, October 09-10, 2020, Tbilisi, Georgia. $103 \mathrm{p}$

38. Natsvaladze 2020b - Natsvaladze M. Unknown sensational episodes of Irakli II's foreign policy. "Resonance" 08/31/2020, pp. 7-8

39. Natsvaladze 01.05.2017 - Natsvaladze M. Was Giorgi the Twelfth Poisoned as per the Order of the Emperor's Royal Court of Russia, "Rezonansi", May 1, 2017. p 15

40. Paichadze 1983 - Treaty of Georgievsk: 1783 Agreement on Eastern Georgia Entering Under Protection of Russia. the text was prepared for publication, the introduction and comments were provided by Giorgi Paichadze; Tbilisi: "Metsniereba", 1983, p. 150.

41. Papashvili 2003 - Papashvili, M. Treaty of Georgievsk, This is Georgia, author and editor Akaki Bregadze. Tbilisi, 2003. pp. 305-313

42. Peradze 2006 - Peradze V. From the History of Relations of Erekle the II with Austria, Historical Verticals. Tbilisi, 2006. N1(10), pp. 82-91

43. Potto 1891 - Potto, V. A. Georgia and Its Historical Past: (Russians Entering Tfilisi in 1783 - Agha Mohammad Khan). Translation by P. Karbelashvili [P. Tskhviloeli]. Iveria, 1891.-26 June, N133, pp.1-2

44. Quigley Carroll 1979 - Quigley Carroll. The evolution of civilizations. An introduction to historical analysis, Publisher: Liberty Fund Inc.; 2nd edition (August 1, 1979). 428 pages

45. Raaflaub Kurt 2010 - Raaflaub Kurt A. (ed.) Thinking, Recording, and Writing History in the Ancient World, Wiley-Blackwell, 2010. 440 p.

46. Ragsdale 1988 - Ragsdale H. Evaluating the traditions of Russian agression: Catherine II and the Greek Project, Slavonic and East Europeen Review. L., 1988. Vol. 66. N 1; pp. 91-117

47. Samsonadze 1988 - Samsonadze M. The problem of the unification of Georgia and foreign orientation in the XVIII century. Tbilisi, Soviet Georgia, 1988, p.318.

48. Shvelidze 2014 - Patronage and conquest of Georgia by Russia, Tbilisi, Meridiani, 2014. p. 154

49. Shvelidze 2012 - Shvelidze D. General Totleben in Georgia. Pro Georgia. Journal of Kartvelological studies. Center for east europiean studies- oriental institute-university of Warsaw. Warsaw T. 22, 2012. s. 107-117.

50. Tamarashvili 1902 - Tamarashvili M., History of Catholicism among Georgians with the introduction and explanations of real documents from the XIII century to the XX century. Tbilisi, published by the author, 1902 , p. 844.

51. Tabaghua 1979 - Tabaghua I., Georgia at the International Arena in the Second Half of the XVIII Century, Tbilisi $1979183 \mathrm{p}$

52. Tsintsadze 1960 - Tsintsadze I., Protective Treaty of 1783: Materials for the history of Russian-Georgian relations, Tbilisi: Sabchota Sakartvelo, 1960 p. 304

53. Tsintsadze 1969 - Tsintsadze, I. Agha Mohammad Khan Attacking Georgia (1795). Tbilisi: "Sabchota Sakartvelo" publishing, 1969. P. 277. 